\title{
Feature Sport News, Before and During Pandemic Covid 19
}

\author{
Fatona Suraya1, Adhi Wijayanto Basuki ${ }^{2}$, Sugiarto $^{3}$, Danti Putri Subagyo ${ }^{4}$ \\ \{suraya@mailunnes.ac.id ${ }^{1}$, adhiwebe@students.unnes.ac.id², sugiarto@mail.unnes.ac.id ${ }^{3}$ \} \\ Universitas Negeri Semarang, Semarang, Indonesia ${ }^{123}$
}

\begin{abstract}
The Covid-19 pandemic has affected the sports news industry, one of which is on featured sports news. This study aims to analyze the differences in the characteristic of feature sport news in ten categories given. A descriptive qualitative research method were implemented with three primary data namely documentation, interview and observation. Of 57 feature sport news, before (August 4, 2019 - November 29, 2019) and during the pandemic (February 29, 2020 - May 29, 2020) were analyzed. The results of this study shows that there is limited difference in quality but a high difference of quantity in feature sport news before and during pandemic. This difference is due to the decrease of sports event during pandemic which result on minimum hard news. Thus, the journalist fill the gap on sports rubric by writing more feature news.
\end{abstract}

Keywords: : feature sport news, Covid-19, characteristic

\section{Introduction}

There is recipe for print media to continue to sell, it must use the $3 \mathrm{~S}$ formula, namely, sex (sex), scandal (scandal) and, sport (sport).[1]. So if you want print media to sell well, print media should present content with at least one of the $3 \mathrm{~S}$ themes[1]. It cannot be denied that news with these three themes is able to attract readers, and is claimed to be the most effective way to attract consumers' attention. The above statement may seem like an anecdote on the one hand, but on the other hand it is real. Sports news has become news that is always present in the daily printed media, in this way it has indeed proven to be an attraction. Drs Moh. As'ad S. Upsi said that attractiveness is an attitude that makes people happy about the object of a situation or certain ideas[2]. This will be followed by feelings of pleasure and a tendency to look for objects that he likes. Meanwhile, the attraction caused by sports news is the factual entertainment value. Given that most humans have a hobby to do sports and have their respective idols. Sports news also contains a lot of good information about idols, clubs, rivals and sports. The appeal of sports news is that it contains an element of entertainment in it and can be a kind of catharsis for some people who want to actualize themselves[2].

Sport news or sport news presented in printed media is not always straight news, but sports news is packaged in the form of features. This makes sports news in the form of a feature serve as an alternative to adding variety to the rubric in print media so that it does not appear monotonous if the news is written only using the straight news format. A typical feature or essay is news that is written creatively and subjectively, especially to entertain readers about an event, a state of one aspect of human life.[2]. Usually, a story writing feature 
begins with something that attracts attention and ends with something to remember. On the other hand, feature stories are still based on facts and data taken through a journalistic process.

Featured news is a creative and subjective article written to entertain and educate readers about an event, circumstance, or aspect of human life [3]. The humans interest aspect is the most prominent aspect. In making a distinctive essay, we must start with something catchy and end with something that will always be remembered. Featured news includes news products that are soft news [4]. This means that the news feature also reports actd factual information obtained from sources [5]. Not much different from straight news, feature news employs the $5 \mathrm{~W}=1 \mathrm{H}$ formula in its publishing. Furthermore, the features are portrayed in a casual creative language [6].

Reporting from the official website page of the National Agency for the Acceleration of Covid-19 Handling, until now Saturday, August 29, 2020, it is stated that there have been 169,151 confirmed cases in Indonesia with 122,758 people recovered and 7,261 people leading to death. Corona virus cases first entered Indonesia on February 14, 2020, to date it has counted to 122,758 cases, this proves that the development of the corona virus is very significant[7]. The emergence of this outbreak also resulted in a temporary suspension of sports competitions, both national and international leagues. As stated in the PSSI decree number 05 / SKEP / I-2001 which was signed by the PSSI general chairman, it states that the official competition termination will take effect from January 21, 2021 through the PSSI Executive Committee (Exco) meeting. With the termination of this kind of competition, will it also have an impact on the print media which provides information based on the results or events in a league competition.

This research refers to the characteristics of the spot news feature before the covid-19 lockdown and during the covid-19 lockdown. Featured characteristics according to [8] there are ten indicators: news writing techniques, news content, news retrieval techniques, news objectives, news series, nature of presentation, journalist code, news copyright, news time, and news structure. According to [9] an indicator is essentially a control variable that can be used to calculate changes in an event or operation. Of the 10 indicators, researchers will take and display a comparison of the characteristics of features sports news after and during the Covid19 pandemic. The research question is how do feature sport news compare in terms of their characteristics before and after the Covid-19 pandemic.

\section{Method}

This study used a qualitative descriptive method with three data sources: observation, interviews and documentation. Qualitative research methods are based on the post positivism philosophy, used to examine the condition of natural objects where the researcher holds the key instrument, the sampling of data sources is done purposively the collection technique is triangulation (combined), the data analysis is inductive and the results of qualitative research emphasize the meaning rather than generalizations [10]. Qualitative research data are in the form of text, photos, stories, pictures, artifacts and not in the form of numbers. The data collection process can be carried out if the direction and objectives of the research are clear and the source of the data is that the informant has been identified, contacted and has received approval of their desire to provide the required information [11]. The data collection process includes observation, interviews and documentation. 
Observation is the collection of data directly from the field [11]. Researchers used an observation rubric validated by the head of the Suara Merdeka Bureaucracy to make observations. The observation rubric consists of 10 indicators of the characteristics of the news it refers to [8]. The results of the observations were used as the basis for preparing interview guidelines. The interview guide has been validated by the relevant validator, namely the head of the Suara Merdeka bureaucracy. The interview method used is a structured interview. Structured interviews are used as a data collection tool if the researcher already knows with certainty what knowledge will be obtained [10]. Sampling in the interview process was carried out by using purposive sampling technique with three sources selected as follows: the deputy head of the bureaucracy, sports journalists and general journalists. The sample for the qualitative approach is purposive, which means that it is in line with the research's goals and objectives [11]. The documentation process was obtained from the sports news data of Suara Merdeka edition, 4 August 2019 to 29 November 2019 and 29 February 2020 to 29 May 2020 .

Table 1. Characteristics Feature Sport News

\begin{tabular}{llccc}
\hline No. & \multicolumn{1}{c}{ Indicator } & Observation & Interview & Documentation \\
\hline 1. & Writing technique (narrating). & $\sqrt{ }$ & $\sqrt{ }$ & $\sqrt{ }$ \\
2. & $\begin{array}{l}\text { The news content is objective, factual } \\
\text { and accurate. }\end{array}$ & $\sqrt{ }$ & $\sqrt{ }$ & $\sqrt{ }$ \\
3. $\quad \begin{array}{l}\text { Data collection technique (projection, } \\
\text { investigation, communication and }\end{array}$ & $\sqrt{ }$ & $\sqrt{ }$ & \\
$\quad \begin{array}{l}\text { confirmation). } \\
\text { 4. News goal (informative and recreation). }\end{array}$ & $\sqrt{ }$ & $\sqrt{ }$ & $\sqrt{ }$ \\
5. $\quad \begin{array}{l}\text { News series (series of facts the facts are } \\
\text { present informally), }\end{array}$ & $\sqrt{ }$ & $\sqrt{ }$ & $\sqrt{ }$ \\
6. $\quad \begin{array}{l}\text { The nature of presentation (factuality). } \\
\text { 7. Journalist code (using full name) }\end{array}$ & $\sqrt{ }$ & $\sqrt{ }$ & $\sqrt{ }$ \\
8. $\quad \begin{array}{l}\text { News copyright (is a weok individual } \\
\text { creative journalist). }\end{array}$ & $\sqrt{ }$ & $\sqrt{ }$ & $\sqrt{ }$ \\
9. News time (using setting and not & $\sqrt{ }$ & $\sqrt{ }$ & $\sqrt{ }$ \\
10. $\quad \begin{array}{l}\text { News structure (outside the inverted } \\
\text { pyramid pattern). }\end{array}$ & $\sqrt{ }$ & $\sqrt{ }$ & \\
\hline
\end{tabular}

After the data is collected, data validity checks are carried out by using the Milles and Hubberman data analysis method.

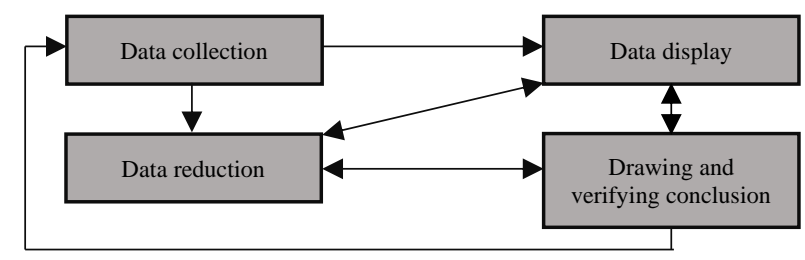

Fig.1. Interactive model data analysis 
The method of qualitative data analysis activities is carried out interactively and continues until the data collected is saturated [10]. Researchers obtained a total of 853 sports news, which were then reduced at the reduction stage by removing non-feature news in order to obtain 53 feature news. The process of data reduction is the process of summarizing, selecting the main things, focusing on the important things, looking for themes and patterns and removing unnecessary data [12]. All feature news is then analyzed using the observation rubric and tested for validity using data analysis belonging to Milles and Huberman. Then the results of the data reduction are presented (display data). In qualitative research, Data presentation in qualitative research can take the form of brief explanations, charts, relationships between categories, flowcharts and so on. The data presentation aims to make it easier for researchers to draw conclusions (verifying conclusions). Initial conclusions are provisional in nature and will change if there is no strong evidence to support the next stage of data collection, if the conclusions are supported by evidence and are consistent, the conclusions put forward are credible conclusions and can be translated into results and discussion.

\section{Results and Discussion}

In the feature sport news characteristic rubric, there are ten indicators:

\subsection{News writing techniques}

Related to the technique of writing news on the feature sport news which aims to tell or to a story as for its characteristics, namely by using a short story writing style that is flexible, lively and alluring. Here are examples the documentation results of news writing methods used before and during the Covid-19 pandemic:

\begin{tabular}{|c|c|}
\hline Before the Covid-19 Pandemic & During the Covid-19 Pandemic \\
\hline $\begin{array}{l}\text { Pada 1992, pundit BBC Sports Alan Hanser } \\
\text { mengkritik keras kebijakan Sir Alex Ferguson. Se- } \\
\text { mentara klub-klub lain berlomba mengumpulkar } \\
\text { pemain bintang, Fergie justru mengusung pa. } \\
\text { sukan akademi: dari David Beckham, Ryan Giggs } \\
\text { Paul Scholes, Nicky Butt, Gary Neville, hingga Phi } \\
\text { Neville ke skuad utama. Ketika itu, MU sedang da- } \\
\text { lam masa kebangkitan sejak mulai ditangani Fer. } \\
\text { gie pada } 1986 \text { dan sempat mengalami masa-ma. } \\
\text { sa puasa gelar. }\end{array}$ & $\begin{array}{l}\text { Benar, George, caramumenciptakan } \\
\text { gol itu sungguh layak dikenang karena } \\
\text { kau seolah-olah menciptakan sesuatu } \\
\text { dari kemuskilan. Kau pasti masih ingat, } \\
\text { ketikakau sedang berlarimembawa bola } \\
\text { ke gawang Verona, teman satu timmu, } \\
\text { Zvonimir Boban, bergumam-gumam, } \\
\text { "Kapan dia mau berhenti? Kapan dia } \\
\text { akan berhenti? Dia takakan berhenti. Dia } \\
\text { tak akan pernah berhenti." }\end{array}$ \\
\hline Fig.2. You Can't Win Anything With Kids [13] & $\begin{array}{l}\text { Fig.3. George Kau Bukan Pemain Lagi or } \\
\text { George, you are not a Player Again [14] }\end{array}$ \\
\hline
\end{tabular}

Based on the results of observations of all feature sport news before and during the Covid-19 pandemic, using news writing techniques to tell stories or to stories [8]. In the news entitled "You Can't Win Anything with Kids" by Amir Machmud using the phrase "Sementara klub-klub lain berlomba mengumpulkan pemain bintang, Fergie justru mengusung pasukan akademi" or "As other clubs compete to gather star players Fergie is actually 
carrying out academy troops" as a lively and attractive style of language. Even so, the language style is also influenced by the characteristics of each journalist. For example, with Saroni Asikin who wrote a feature work entitled "George, Kau Bukan Pemain Lagi" or "George, you are not a Player Again", using diction that is rarely used by people in general, such as "Caramu menciptakan gol itu sungguh layak dikenang karena kau seolah-olah menciptakan sesuatu dari kemuskilan " or "The way you create goals is truly memorable because you seem to create something out of obscurity".

Although the news writing technique before and during the Covid-19 pandemic was consistent with the theory, journalists who write news have a significant impact on how a flexible, lively and attractive language style is applied to writing through the ability to use the language style of the journalists themselves. In rhetoric, language style is often referred to as "style," which refers to the ability or abilities to write or use beautiful words [15].

According to the results of an interview with the deputy head of the Suara Merdeka bureaucracy, the main characteristic of a feature news writing technique is, "Unlike straight news which aims to inform, features prioritize telling stories about facts or information. Therefore, in the process of writing a feature that aims to tell stories, it can be seen from various styles of language and diction". In this news writing technique indicator, there are as many as 16 news stories before the pandemic period and 37 news during the pandemic period which have a to story writing technique.

\subsection{News content}

Related to the content of the news in the sports news feature, which is objective, factual, true and accurate, while the features are by using a channel and a lighter in the delivery of the news. For example, here are the results of news content documentation before and during the Covid-19 pandemic:

\begin{tabular}{|c|c|}
\hline Before the Covid-19 Pandemic & During the Covid-19 Pandemic \\
\hline $\begin{array}{l}\text { Banderol Couyang dibeli Barca dari } \\
\text { Liverpool Rp } 2,6 \text { triliun pada } 2017 \\
\text { menjadi pengganjal. Maka hijrah ke } \\
\text { Bayern Muenchen dengan status } \\
\text { pinjaman menjadi opsi terbaik bagi } \\
\text { pemain berjejuluk "Si Penyihir Kecil" } \\
\text { itu. }\end{array}$ & $\begin{array}{l}\text { Selain kariemya yang cemerlang, petenis asal Rusia } \\
\text { ini juga mengalami masa terendah dalam kariernya. Pada } \\
2016 \text { lalu, Sharapova tersandung masalah doping menje- } \\
\text { lang tumamen Australia Open } 2016 \text { dan menjalani skors } \\
15 \text { bulan. }\end{array}$ \\
\hline $\begin{array}{l}\text { Fig.4. Couthino dan Habitat Bersenang- } \\
\text { senang or Coutinho and Habitat Having } \\
\text { Fun [16] }\end{array}$ & $\begin{array}{l}\text { Fig.5. Siap Bersaing di Medan Berbeda or Ready } \\
\text { to Compete in a Different Field [14] }\end{array}$ \\
\hline
\end{tabular}

Based on the results of observations of all sports news feature news before and during the Covid-19 pandemic, the content of news about events is objective, factual, true and accurate [8]. The data contained in the news content is objective, factual and accurate. This is illustrated by the sentence in the news entitled "Coutinho dan Habitat Bersenang-senang" or "Coutinho and Habitat Having Fun" in the sentence "Banderol Cou yang dibeli Barca dari Liverpool Rp 2,6 triliun pada 2017 menjadi pengganjal" or "The official coupon that Barca purchased from Liverpool for Rp. 2.6 trillion in 2017 has been a booster". And "Pada 2016 lalu, Sharapova tersandung masalah doping menjelang tournament Australia Open 2016" or "In 2016, Sharapova stumbled over a doping problem ahead of the Australian Open 2016 
tournament" in a feature news entitled "Siap Bersaing di Medan Berbeda" or "Ready to Compete in a Different Field". The two sentences explain that the data or information contained in the news content contains objective, factual, true and accurate characteristics.

According to the findings of interviews with the deputy head of the Suara Merdeka bureaucracy, it was stated that the main feature of news content that is objective, factual, true and accurate is "Sentences used in sports news features use factual lines and lighters, this is intended to make the features relevant to read the next 10 years and out of date'. In this news content indicator, there are as many as 16 news stories before the pandemic period and 37 news during the pandemic period which contain news that is objective, factual, true and accurate.

\subsection{News techniques}

Related to news retrieval techniques on sports news features, namely by methods or through projection, observation, investigation, communication and confirmation processes. For example, here are the documentation results of news-taking techniques before and during the Covid-19 pandemic:

\begin{tabular}{|c|c|}
\hline Before the Covid-19 Pandemic & During the Covid-19 Pandemic \\
\hline $\begin{array}{l}\text { Sangpelatih, bisapula dipahami, } \\
\text { mulai kehilangan kepercayaan } \\
\text { karena performa Cou tak kunjung } \\
\text { membaik. Pemain } 27 \text { tahun itu pun } \\
\text { makin lama makin kehilangan konf-- } \\
\text { densi lantaran pressure psikologis } \\
\text { yang menyebabkan sulit menun- } \\
\text { taskan kemampuannya. } \\
\text { Keluarga be sar Bayern me- } \\
\text { nyambutnya, dan percaya pemain } \\
\text { dengan tembakan-tembakan plac- } \\
\text { ing dari luar kotak penalti itu bakal } \\
\text { menuai sukses di Bundesliga. } \\
\text { "Kalau sudah } 100 \text { persen fit, dia } \\
\text { bakal menjadi pembeda di sini," } \\
\text { ungkap Benjamin Pavard, bek } \\
\text { Bayern asal Prancis. }\end{array}$ & 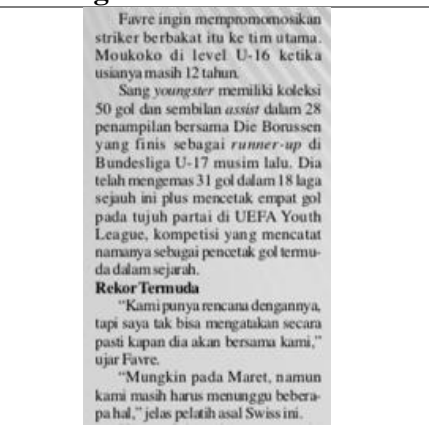 \\
\hline
\end{tabular}

Fig.6. Couthino dan Habitat Bersenang-senang Fig.7. Talenta Luar Biasa or Talenta $\begin{array}{ll}\text { or Cou and Habitat to Have Fun [16] } & \text { Extraordinary [17] }\end{array}$

Based on the results of observations of all feature sport news before and during the Covid-19 pandemic, the data collection process is through projection, observation, investigation, communication and confirmation [8]. "Pemain 27 tahun itu pun makin lama makin kehilangan konflidensi lantaran pressure psikologi yang menyebabkan sulit menuntaskan kemampuanya" or The 27-year-old player is increasingly losing his conflict due to psychological pressure which makes it difficult to complete his abilities" in a feature news entitled "Cou dan Habitat Bersenang-senang" or "Cou and Habitat to Have Fun" states that journalists have made observations on Coutinho's performance, while the statement expressed by Bejamin Pavard in the last paragraph is a form of communication as well as confirmation from the source.

In a feature story entitled "Talenta Luar Biasa" or "Talenta Extraordinary" by Edi Indiarto, sentences that prove projections, observations and investigations are contained in the second paragraph. "Mungkin pada Maret, namun kami masih harus menunggu beberapa hal" or "Maybe in March, but we still have to wait a few things", was a line explaining the communication and confirmation. From the results of the interview with the deputy head of 
the Suara Merdeka bureaucota, it was stated that the main characteristic of the news retrieval technique was "Collecting relevant data before being correlated with the facts contained in an event or obtained from sources, this is what makes the feature more weigh because of the time it takes to process it. not easy and takes a little longer".

\subsection{News purposes}

Related to the purpose of news in the sports news feature, namely conveying information as well as entertaining (informative and recreational). For example, here are the documentation results of news destinations before and during the Covid-19 pandemic:

\begin{tabular}{cc}
\hline \multicolumn{1}{c}{ Before the Covid-19 Pandemic } & During the Covid-19 Pandemic \\
\hline $\begin{array}{l}\text { Ucapan Hansen, yang kemudian menjadi } \\
\text { "tagline" populer dan diproduksi dalam berbagai } \\
\text { properti pun laris manis di pasar mediatika Kritik } \\
\text { berbalik menghantam dirinya, karena visi Fergie } \\
\text { terbukti berada di jalur tepat. Dengan anak-anak } \\
\text { akademi itu The Red Devils bergerak menjadi ke- } \\
\text { kuatan hebat Liga Primer Inggris. Mereka mene- } \\
\begin{array}{l}\text { mukan puncak kematangan pada 1999 dengan } \\
\text { meraih trebel liga, Piala FA, dan Liga Champions. }\end{array}\end{array}$ & $\begin{array}{c}\text { YA, George, golmu itu abadi, tapi tak } \\
\text { ada pujaan untuk manusia yang bersifat } \\
\text { abadi. Pujaan untukmu juga tak abadi. } \\
\text { Lebih-lebih sekarang kau sedang } \\
\text { banyak dicerca. }\end{array}$ \\
\hline Fig.8. You Can't Win Anything With Kids [13] & $\begin{array}{l}\text { Fig.9. George Kau Bukan Pemain Lagi or } \\
\text { George, you are not a Player Again [14] }\end{array}$ \\
\hline
\end{tabular}

Based on the results of observations of all feature sport news before and during the Covid19 pandemic, the purpose of news is to convey information as well as be entertaining or informative and recreational [8]. The informative form is found in the informed data, while the recreation is in the language style setting that binds the delivery of the data or information. Amir Machmud conveyed information that MU broke the treble winner in 1999 with the words "Dengan anak-anak akademi itu The Red Devil bergerak menjadi kekuatan hebat Liga Primer Inggris" or "With these academy boys, The Red Devil moved to become a great force for the English Premier League" in a feature news entitled "You Can't Win Anything with Kids".

Meanwhile, Saroni Asikin in the news "George Kau Bukan Pemain Lagi" "George, you are not a Player Again" or compared Goerge's current condition with his heyday through his language style and diction. From the sentence above, it is evident that the delivery of information is also accompanied by a language style that aims to entertain the reader. According to the results of an interview with the deputy head of the Suara Merdeka bureaucracy, it was stated that the main characteristic of an informative and recreational news objective is, "All news aims to provide information that is in the feature besides providing information, it is also required to be entertaining (recreational). This is intended so that the feature does not only touch the cognitive area but also touches the affective area of the reader". In this news objective indicator, there are as many as 16 news items before the pandemic period and 37 news items during the pandemic period which have informative and recreational news purposes.

\subsection{News series}

Related to a series of news in the feature sport news a series of facts or information presented in an informal, informal manner. For example, here are the documentation results from a series of news before and during the Covid-19 pandemic: 
Before the Covid-19 Pandemic

SENTUHAN Pep lantas mendunia. Setelah empat musim berada di Camp Nou, dia menerima tawaran membesut Bayern Munich pada2013. Sang mantan playmaker ini tetap seorang perfeksionis. Namun, dia tak bisa lepas dari "virus" minta bintang.

Ditarget meraih trofi Liga Champions, Pep gagal total bersama Die Roten. Dia hanya sanggup mempersembahkan titel domestik, yakni kampiun Bundesliga dan Piala DFB.

Dalam kegelisahannya kemudian datang tawaran menggiurkan dari Manchester City.

Pada musim pertamanya, 2016-2017, Pep dibuat kaget lantaran gagal memberi trofi The Citizens. Manajemen tetap memercayainya. Misi utamanya adalah membawa trofi Liga Champions ke Stadion Etihad.

\section{During the Covid-19 Pandemic Setan Merah Tak Lagi Merindukan Pogba}

BRUNO Fernandes tak kesulitan beradaptasi dengan kultur sepak bola Inggris yang identik dengan permainan intens. Bahkan, dia tak butuh waktu lama untuk nyetel dengan para pemain Manchester United setelah didatangkan dari Sporting Lisbon pada bursa transfer Januari 2020 lalu.

Kehadirannya langsung berdampak signifikan untuk The Red Devils. Dengan kecerdasandankreativitasnya di lini tengah, pemain asal Portugal ini ikut membantu mengangkat performa rekan-rekan setimnya menjadi lebih baik.

Dia tidak hanya memanjakan penyerang-penyerang Unitedlewat umpan-umpanterukur, tapi juga mendorong gelandang lain seperti Juan Mata mengeluarkan kemampuan terbaik. Hasilnya, permainan Setan Merah lebih hidup dan sering meraih hasil maksimal.

"Diadatang dandia sepertimenjadi udarasegar untuk bernapas. Dia datang dan tampak seperti seserang yang ingin bermain sepak bola serta menikmati sepak bola," kata legenda Manchester United Rio Ferdinand.

Fig.10. Virus Minta Pemain TOP or

Viruses Ask the TOP Players [18]

Fig.11. Setan Merah Tak Lagi

Merindukan Pogba or Red Devils No

Longer Miss Pogba [19]

Based on observations of all feature sport news before and during the Covid-19 pandemic, the news series are not presented formally [8]. Presentation of features is informal. It can be seen in the lead of a news story or the first paragraph, if in direct news or straight news the content of the news can be known only by reading the lead (first paragraph), because of the nature of straight news to report and presenting information in a concise, concise and, straightforward manner. However, in contrast to features, each section of a feature paragraph relates to each other using relaxed language and even uses figures of speech, the aim of which is to touch the emotions of the reader.

According to the results of an interview with the deputy head of the Suara Merdeka bureaucracy, the main characteristic of a series of news that is presented informally is that "In a feature, the form of a news series is not like straight news, which is only in plates, but is presented in a more varied manner. This is due to spreading points. The information points in each paragraph are intended to be able to describe the events that occur in an engaging narrative. In this news series indicator, there are 16 news stories before the pandemic period and 37 news stories during the pandemic period which have an informal news series.

\subsection{Nature of news presentation}

Regarding the nature of the presentation on the feature sport it is not captivated by actuality. For example, here are the documentation results of the nature of the presentation before and during the Covid-19 pandemic: 


\begin{tabular}{|c|c|}
\hline Before the Covid-19 Pandemic & During the Covid-19 Pandemic \\
\hline $\begin{array}{l}\text { OLE Gunnar Solkjaer menghela napas pan- } \\
\text { jang. Lega Muka imutnya terlihat semringah keti- } \\
\text { ka meninggalkan area Stadion Partizan, Kamis } \\
\text { (24/10) malam itu. Tim asuhannya, Manchester } \\
\text { United (MU), menang versus Partizan Belgrad } \\
\text { pada lanjutan penyisihan Grup L Liga Eropa Ha- } \\
\text { nya } 1-0 \text {. Itu pun lewat sepakan penalti Anthony } \\
\text { Martial pada menit ke-43 menyusul pelanggaran } \\
\text { pemain Partizan terhadap Brandon Williams. ... }\end{array}$ & $\begin{array}{l}\text { Gasperini memang bukan allenatore } \\
\text { papan atas. Dia cuma sekali menukangi } \\
\text { klub besar, yakni Inter Milan pada } 2011 . \\
\text { Di luar itu, pemilik rambut perak ini mem- } \\
\text { besut Crotone (2003-2006), Genoa } \\
\text { (2006-2010), Palermo (2012-2013), } \\
\text { Genoa (2013-2016), dan Atalanta sejak } \\
2016 \text {. . . . . . . . . }\end{array}$ \\
\hline $\begin{array}{l}\text { Fig.12. Mempercayai Para Taruna or Trusting the } \\
\text { Taruna [20] }\end{array}$ & $\begin{array}{l}\text { Fig.13. Klub Dengan Bahan Bakar Semangat } \\
\text { or The Club Fueled by Passion [19] }\end{array}$ \\
\hline
\end{tabular}

Based on the results of observations of all feature sport news before and during the Covid-19 pandemic, the nature of the presentation is factual, namely using data or facts that are based on the truth and the fact that is out of date.[8]. In the news entitled "Mempercayai Para Taruna" or "Trusting the Taruna" by Saroni Asikin, it is explained that the data in conveying the information is factual. This is contained in the sentence "Muka imutnya terlihat sumringah Ketika meninggalkan area Stadion Partizan, Kamis (24/10) malam itu" or "His cute face looked happy when he left the Partizan Stadium area, Thursday (24/10) that night". Meanwhile, Edi Winarto proves the nature of factuality by writing the sentence "Diluar itu, pemilik rambut perak ini membesut Crotone (2003-2006), Genoa (2006-2010), Palermo (2012-2013), Genoa (2013-2016), dan Atlanta sejak 2016" or "Apart from that, the owner of silver hair has refined Crotone (2003-2006), Genoa (2006-2010), Palermo (2012-2013), Genoa (2013-2016), and Atlanta since 2016.".

According to the results of an interview with the deputy head of the Suara Merdeka bureaucota, the main characteristic of the presentation that is not captivated by actuality is that "The data used in the features, especially the sports news feature, are factual data, for example the record data for MU's victory last season. written a feature with Liverpool's record winning record this season. This shows that the data contained in the feature does not have to be the latest (actual) data". In the indicator of the nature of the presentation of this news, there are as many as 16 news stories before the pandemic period and 37 news during the pandemic period which have the nature of presenting news that is objective, factual.

\subsection{Journalist code}

Related to the journalist code in the feature sport news, it can be seen at the end of the news paragraph, namely in the form of a full name. Based on the results of observations of all feature sport news before and during the Covid-19 pandemic, the journalist code contained in the sports news feature news is the full name. In the Sunday edition of the daily Suara Merdeka, 18 August 2019, three sports news features were seen, each of which was written by Alwin Basri, Budi Winarto, and Arif M Iqbal. Meanwhile, during the pandemic, the Sunday edition, March 29, 2020, there were also features written by Krisnaji Satriawan and Darjo Soyat, respectively. There is no difference either before or during the Covid-19 pandemic in writing journalistic code in this feature story.

According to the results of an interview with the deputy head of the Suara Merdeka bureaucota, the main characteristic of the journalist code is the full name, which is "If in straight news the journalist code is written only using the initials of the name and number, it is inversely proportional to the feature that uses the full name. and to be a form of appreciation 
for the journalist who wrote the feature". In this journalist code indicator, there are 16 news items before the pandemic period and 37 news items during the pandemic period which have a journalist code in the form of the journalist's full name. For example, here are the documentation results from journalist codes before and during the covid-19 pandemic:

\begin{tabular}{|c|c|}
\hline Before the Covid-19 Pandemic & \multirow{4}{*}{$\begin{array}{l}\text { During the Covid-19 Pandemic } \\
\text { Fl telah menggelar balapan virtual untuk mengis } \\
\text { kekosongan tujuh balapan awal musim 2020. Dilansi } \\
\text { dari Crash, semua pembalap diundang untuk } \\
\text { mengikuti balapan virtual tersebut. Seri pertama akar } \\
\text { dimulai pada seri Bahrain, Minggu (22/3) lalu } \\
\text { (Krisnaji Satriawan-67) }\end{array}$} \\
\hline rapkan tuntas pada Desember mendatang. & \\
\hline (Alwin Basri, pengamat FI-47) & \\
\hline $\begin{array}{c}\text { gemar melakukan tukar pukulan } \\
\text { dalam standing fight. (Budi } \\
\text { Winarto-47) }\end{array}$ & \\
\hline $\begin{array}{l}\text { masing-masing pemain selama berada di akademi. (Arif } \\
\text { M Iqbal-29) }\end{array}$ & $\begin{array}{l}\text { Kita nggak ngomongin juara ya, kare- } \\
\text { na juara juga kadang butuh faktor } \\
\text { luck," sambung Nova. (Darjo Soyat- } \\
67\end{array}$ \\
\hline $\begin{array}{l}\text { Fig.14. Suara Merdeka, Sunday edition, } 18 \\
\text { August } 2019 \text { [21] }\end{array}$ & $\begin{array}{l}\text { Fig.15. Suara Merdeka, Sunday } \\
\text { edition, } 29 \text { March } 2020 \text { [22] }\end{array}$ \\
\hline
\end{tabular}

\subsection{News copyright}

Related to news copyright on the feature sport news can be seen in the journalist's code. For example, here are the documentation results of copyrighted news before and during the covid-19 pandemic before and during the covid-19 pandemic:

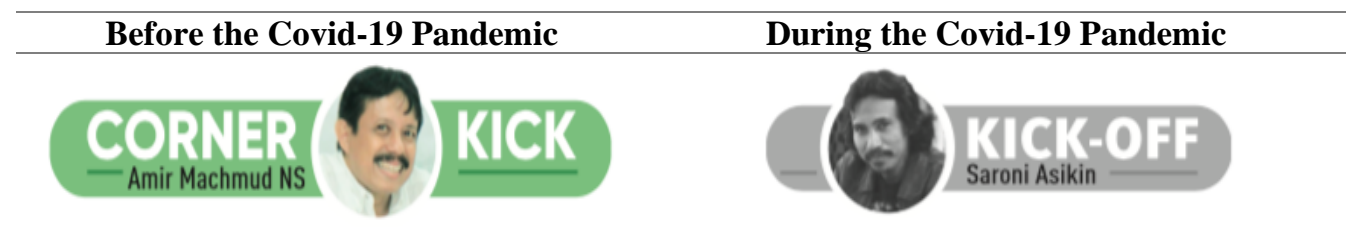

Fig.16. You Can't Win Anything With Kids [13]

Fig.17. George Kau Bukan Pemain Lagi or George You're Not a Player Again [14]

Based on the results of observations of all feature sport news before and during the Covid-19 pandemic, the copyright of the news contained in the sports news feature is in the form of a journalist's full name. There is no difference to copyright either before or during the Covid-19 pandemic. According to the results of an interview with the deputy head of the Suara Merdeka bureaucracy, it was stated that the main characteristic of news copyright is the full name "a feature that uses the full name, this is due to more accountability and to be a form of appreciation for the journalist who wrote the feature". In this news copyright indicator, there are 16 news stories before the pandemic period and 37 news stories during the pandemic period which have copyright news.

\subsection{News time}

Related to the time of the news on the feature sport news can be seen in the first paragraph or intro. For example, here are the documentation results from the news time before and during the pandemic Covid-19: 


\begin{tabular}{|c|c|}
\hline Before the Covid-19 Pandemic & During the Covid-19 Pandemic \\
\hline $\begin{array}{l}\text { MEMBICARAKAN Liverpool } \\
\text { saat ini tidak klop kalau tak men- } \\
\text { gangkat peran manajernya, } \\
\text { Juergen Klopp. Pelatihasal Jeman } \\
\text { yang menukangi The Reds sejak } 8 \\
\text { Oktober2015 itubenar-benarmen- } \\
\text { jadi kesayangan Liverpudlian. } \\
\text { Kinerjanya oke, hasilnya pun terli- } \\
\text { hatnyata. }\end{array}$ & $\begin{array}{l}\text { Kegundahan Vettel, } \\
\text { Keberanian Ferrari } \\
\text { KEGUNDAHAN Sebastian Vettel akhirnya } \\
\text { berbuah kepastian. Pembalap Formula } 1 \text { (F1) } \\
\text { asal Jerman itu memutuskan meninggalkan Tim } \\
\text { Scuderia Ferrari setelah musim } 2020 \text { selesai. } \\
\text { Keputusan juara dunia empat kali itu sekaligus } \\
\text { menegaskan ambisinya untuk juara masih tinggi. } \\
\text { Saya memahami, pada usia } 32 \text { tahun, pelu- } \\
\text { ang Vettel untuk menambah gelamya masih ter- } \\
\text { buka. Agar kans itu membesar dia butuh peng- } \\
\text { akuan sebagai pembalap utama di timnya. } \\
\text { Sayang, Ferrari mulai meragukan kemampuan } \\
\text { mantan driver Red Bull ini. }\end{array}$ \\
\hline $\begin{array}{l}\text { Fig.18. Mengedepankan Keseimbangan or } \\
\text { Promoting Balance [23] }\end{array}$ & $\begin{array}{l}\text { Fig.19. Kegundahan Vettel, Keberanian } \\
\text { Ferarri or Vettel's Worries, Ferrari } \\
\text { Courage [22] }\end{array}$ \\
\hline
\end{tabular}

Based on the results of observations of all feature sport Based on the results of observations of all sports news feature news before and during the Covid-19 pandemic, the time of the news contained in the sports news feature news is in the form of a lighter, not the date of the event. In a feature story entitled "Mengedepankan Keseimbangan" or "Promoting Balance" by Edi Indarto, uses the word "Membicarakan" or "Talking about" at the beginning of the sentence in the intro. Meanwhile, Darjo Soyat uses the word "Kegundahan" or "Anxiety" to initiate the intro. In contrast to straight news, the beginning of the sentence uses the date time or city name. According to the results of the interview with the deputy head of Suara Merdeka, it was stated that the main characteristic of the news time is "If in a feature, the time in the news is indicated by the date or day while in the feature it is shown by setting either the name of the person or the event in the intro". In this news time indicator, there are as many as 16 news items before the pandemic period and 37 news items during the pandemic period which have news time using the description of the setting.

\subsection{News structure}

Related to the structure of the news in the feature sport news can be seen in the paragraphs that are important to each other. Based on observations of all feature sport news before and during the Covid-19 pandemic, the structure of the news contained in sports news feature news is in the form of messages at the beginning of a paragraph and is not bound by an inverted pyramid. There is no difference in the structure of the news both before and during the Covid-19 pandemic. According to the results of an interview with the deputy head of the Suara Merdeka bureaucota, the main characteristic of the inverted pyramid pattern structure is "Because the features are written not using $5 \mathrm{~W}+1 \mathrm{H}$ (inverted pyramid pattern), each paragraph section in the feature is equally important, this is why reading features cannot be used. in pieces". There are 16 news stories before the pandemic era and 37 news stories during the pandemic period in this news structure indicator that have a news structure outside the inverted pyramid. For example, here are the documentation results of copyright news before and during the covid-19 pandemic: 


\begin{tabular}{|c|c|}
\hline Before the Covid-19 Pandemic & During the Covid-19 Pandemic \\
\hline 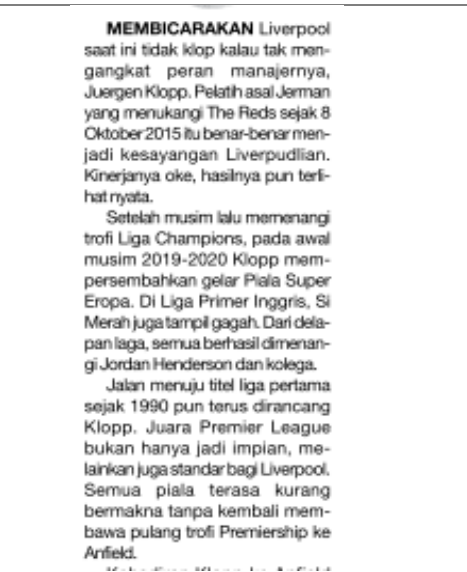 & $\begin{array}{l}\text { Meski baru berusia } 32 \text { tahun tetapi Sharapova kesulit- } \\
\text { an untuk bermain maksimal. Salah satu penyebab } \\
\text { penampilannya menurun adalah cedera bahu. Dalam tiga } \\
\text { hajatan Grand Slam terakhir, mantan petenis putri nomor } \\
\text { satu dunia itu senantiasa tersingkir di babak pertama. } \\
\text { Bahkan, kini peringkatnya terus menurun hingga } 373 \\
\text { dunia. Posisi ini merupakan yang terendah baginya sejak } \\
\text { Agustus } 2002 \text {. } \\
\text { "Saya masih baru dalam hal ini, jadi tolong maafkan } \\
\text { diriku. Ten is, saya mengucapkan selamat tinggal," } \\
\text { ungkap Sharapova dalam sebuah wawancara kepada } \\
\text { majalah Vogue and Vanity Fair. } \\
\text { "Mengenang kembali ke masa lalu, saya menyadari } \\
\text { tenis sudah menjadi gunung untuk diriku. Saya berjalan } \\
\text { menyusuri lembah dan berliku-liku, tapi pemandangan- } \\
\text { nya daripuncak luar biasa. Tapi usai } 28 \text { tahundan lima titel } \\
\text { Grand Slam, saya siap untuk mendaki gunung lain, untuk } \\
\text { bersaing di medan yang berbeda," imbuhnya. }\end{array}$ \\
\hline
\end{tabular}

Fig.20. Mengedepankan Keseimbangan Fig.21. Siap Bersaing di Medan Berbeda or Promoting Balance [23] or Ready to Compete in Different field [14]

\section{Conclusion}

The results of this research indicate that all feature sports news in the daily newspaper Suara Merdeka, both before the Covid-19 pandemic and during Covid-19 followed the ten feature characteristic indicators, which are news writing techniques, news content, news retrieval techniques, news objectives, news series, the nature of news presentation, journalist code, news copyright, time/setting and news structure. However, the differences lie in the number of the news. There are more feature sports news produces during the pandemic which likely due to the cancellation of some sports tournament. This phenomenon forced the journalist to be more creative in making content to fill the sports page, one of which through writing more feature news. This study depends only on the suaramerdeka.com site for 91 days before and during covid. Before covid 19 there are 5 days file that could not be accessed and during covid 19 there are 3 files could not be accessed. Further research needs to have access to all news based on the time duration to avoid bias.

\section{Acknowledgments}

The research process that took place during the Covid-19 pandemic that occurred in Indonesia forced us to conduct research in the middle of the Covid-19 pandemic by complying with health protocols as recommended by the government. We would also like to thank friends and family members who assisted in keeping this research going. Thank you to the daily newspaper Suara Merdeka for granting permission and support for this research, allowing it to continue as expected. We would like to thank our sources for being willing to be a resource person as well as a source of data in our analysis. 


\section{References}

[1] N. M. Prarstya, "Geliat Surat Kabar Harian Olahraga di Indonesia,” J. Komun., vol. 6, 2011.

[2] R. N. A. Loureiro, "DAYA TARIK JURNALISTIK, PERS, BERITA DAN PERBEDAAN PERAN DALAM NEWS CASTING,” Journal, no. april, pp. 1-12, 2016.

[3] Wahyuwibowo and I. Seto, Pengantar Jurnalistik: Teknik Penulisan Berita, Artikel \& Feature, NA. Jogjakarta: Lokomedia, 2015.

[4] N. Widiasari, “Analisis Isi Berita Corporate Social Responsibility," Interact, vol. 1, no. 2, pp. 4657, 2012.

[5] S. Wulan, "Memahami Kebijakan Redaksional Rubrik Pendidikan di Surat Kabar Harian Solopos," J. Messenger, vol. 7, no. 2, p. 18, 2016.

[6] K. Analisis, W. Teun, A. Asriyanti, F. Muhammad, and R. Latief, "REALITAS KEMANUSIAAN DALAM RUBRIK SOSOK HARIAN," vol. 1, no. 1, pp. 154-168, 2020.

[7] T. Singhal, "A Review of Coronavirus Disease-2019 (COVID-19)," vol. 87, no. April, pp. 281286, 2020.

[8] Juwito, Menulis Berita Dan Features. Surabaya: Unesa University Press - 2008, 2008.

[9] B. T. Endaryono and T. Djuhartono, "Indikator Pembangunan Pendidikan Untuk Masyarakat Berkelanjutan Dengan Pendidikan Berkarakter Di Indonesia,” J. Ilm. Kependidikan, vol. 4, no. 3, pp. 301-306, 2017.

[10] P. D. Soegiyono, METODE PENELITIAN PENDIDIKAN Pendekatan Kuantitatif, Kualitatif dan R\&D. Bandung: ALFABETA CV, 2012.

[11] J. Raco, "Metode penelitian kualitatif: jenis, karakteristik dan keunggulannya," 2018.

[12] S. Pradoko, PARADIFMA METODE PENELITIAN KUALITATIF, NA. Jogjakarta: UNY Press, 2017.

[13] A. Machmud, "You Can't Win Anything with Kids," no. 17, Semarang, p. 2019, 2019.

[14] S. Asikin, "George Kau Bukan Pemain Lagi," no. 17, Semarang, p. 2020, 2020.

[15] G. Keraf, "Diksi dan Gaya Bahasa." pp. 130-136, 2006.

[16] A. Machmud, "Choutinho dan Habitat Bersenang-senang," vol. 2019, no. September, p. 2019, Sep-2019.

[17] E. Indiarto, "Talenta Luar biasa," no. 17, Semarang, p. 2020, 2020.

[18] E. Indarto, "Virus Minta Pemain TOP," no. November 2019, Semarang, p. 2019, Nov-2019.

[19] B. Winarto, "Setan Merah Tak Lagi Merindukan Pogba," no. 17, Semarang, p. 2020, 2020.

[20] S. Asikin, "Mempercayai Para Taruna," no. 47, Semarang, p. 2019, 2019.

[21] A. Basri, "Spirit Olahraga edisi Mingguan," Semarang, p. 2019, 2019.

[22] D. Soyat, "ESport Dalam Pandemi Covid-19," no. 17, Semarang, p. 2020, 2020.

[23] E. Indarto, “Mengedepankan Keseimbangan,” no. 17, Semarang, p. 2019, 2019. 